OPEN ACCESS

Edited by:

Rabi Mohtar,

Texas A \& M University, United States

Reviewed by:

Nitin Kaushal,

World Wide Fund for Nature, India

Marcos Callisto,

Universidade Federal de Minas Gerais,

Brazil

*Correspondence:

Ines Dombrowsky

ines.dombrowsky@die-gdi.de

Specialty section

This article was submitted to

Freshwater Science,

a section of the journa

Frontiers in Environmental Science

Received: 06 July 2018 Accepted: 03 December 2018

Published: 18 December 2018

Citation:

Dombrowsky I and Hensengerth $O$ (2018) Governing the Water-Energy-Food Nexus Related to Hydropower on Shared Rivers-The

Role of Regional Organizations.

Front. Environ. Sci. 6:153

doi: 10.3389/fenvs.2018.00153

\section{Governing the Water-Energy-Food Nexus Related to Hydropower on Shared Rivers - The Role of Regional Organizations}

\author{
Ines Dombrowsky ${ }^{1 *}$ and Oliver Hensengerth ${ }^{2}$ \\ ${ }^{1}$ Programme Environmental Governance and Transformation to Sustainability, German Development Institute/Deutsches \\ Institut für Entwicklungspolitik, Bonn, Germany, ${ }^{2}$ Department of Social Sciences, Northumbria University, Newcastle upon \\ Tyne, United Kingdom
}

An evolving literature on the Water-Energy-Food (WEF) nexus argues that there is a need to better understand the conditions under which nexus coordination may occur. A case in point are hydropower investments on shared rivers which might impact the provision of energy, water and food security across borders. In international basins, governing the WEF nexus impacts of hydropower relies on voluntary negotiations between the respective countries involved. It has been argued that such negotiations may be facilitated by regional organizations, such as international river basin organizations (IRBOs), but this claim has hardly been investigated systematically. Drawing on regime theory in international relations and the literature on benefit sharing, this paper asks what role regional organizations may play in governing hydropower-related WEF nexus impacts. It compares three cases of hydropower planning on shared rivers. The Rusumo Falls and the Ruzizi III hydropower projects (HPPs) are joint investments in Africa's Great Lakes region facilitated by an IRBO and a regional energy organization, respectively. On the Mekong, Laos is constructing the Xayaburi dam despite reservations by the Mekong River Commission and downstream riparians. The paper finds IRBOs and regional energy organizations may play a role in facilitating cross-border nexus governance by supporting benefit-sharing arrangements and by fostering the application of environmental and social safeguards and international law principles. However, it also shows that the influence of regional organizations varies, and how successfully they support nexus governance also depends on whether the HPP is planned unilaterally or jointly; the availability and consensus on data on nexus impacts; and the presence or absence of donors and private sector capital and investors.

Keywords: water-energy-food nexus, governance, hydropower, transboundary river, river basin organization, Rusumo Falls, Ruzizi III, Xayaburi 


\section{INTRODUCTION}

In international river basins, hydropower projects (HPPs) generate multiple cross-border, cross-sector interdependencies related to water, energy and food security. Many African and Asian countries have been investing strongly in hydropower to supply their rapidly growing economies (IHA, 2017). Many of these investments take place along international rivers. While the main purpose of hydropower is to contribute to energy security, dams often negatively affect water and food security and ecosystems services by blocking fish migration routes, destroying fertile agricultural lands and leading to the eviction of projectaffected communities. Hence, investments in HPPs may raise several issues in relation to the water-energy-food (WEF) nexus by one-sidedly focusing on energy production, but neglecting the impact on water and food security.

The WEF nexus debate acknowledges the increasing interconnectedness of water, energy and land resources [sometimes referred to as the WEL nexus, e.g., ODI et al. (2012)] in providing water, energy and food security [WEF nexus, e.g., Hoff (2011), WEF-WI (2011)] for a rising world population under conditions of economic growth and climate change. For instance, Müller et al. (2015) point out how four output dimensions, namely the provision of water, energy and food security and a world of less than two degrees warming increase pressures on inputs such as soil, water and biodiversity and the ecosystem services they provide. Hence, pursuing one security may go along with synergies and trade-offs related to the other securities. Nexus thinking therefore argues for mobilizing synergies and managing critical trade-offs (Hoff, 2011; WEF-WI, 2011; ICSU, 2017). Still, the term WEF nexus has no globally agreed definition. Lebel and Lebel (2018) identify politicized and de-politicized notions of the term. Some of these notions carry positive connotations, while others are negative, depending on the actors involved and their attitudes toward a particular development project [for other conceptualizations of nexus see Keskinen et al. (2016)].

Despite a wide-ranging WEF literature investigating synergies and trade-offs in the provision of water, energy and food securities, Weitz et al. (2017) point out that our understanding of what governing the WEF nexus means and under which conditions it works or not remains very limited and more empirical work on the matter is warranted (see also VillamayorTomas et al., 2015). This paper therefore seeks to contribute to the evolving literature on governing the WEF nexus by providing a more in-depth analysis of the case of hydropower investments on shared rivers and the role that regional organizations may have in governing nexus impacts.

Some authors argue that in a transboundary context, regional basin organizations may be particularly well-positioned to govern nexus impacts due to their access to key actors in relevant sectors and across geographical scales (e.g., UNEP, 2014; Scheumann and Tigrek, 2015). We investigate these arguments by drawing on the literature on regime theory and the literature on benefit sharing in order to investigate the role of regional organizations in the transboundary governance of the waterenergy-food nexus (hereinafter "nexus governance") related to hydropower investments along international rivers. Empirically, we focus on three recent investments into hydropower on shared rivers: the Ruzizi III, Rusumo Falls, and Xayaburi dam projects. Drawing upon Paavola (2007) and Müller et al. (2015), the paper understands nexus governance as a dynamic and recursive process involving state and non-state actors who establish, reaffirm or change institutions to resolve conflicts and negotiate political decisions in a way that takes into account interdependencies between soil, water and biodiversity systems in the provision of water, energy and food security.

The section on WEF Nexus, HPPs and the Potential Role of Regional Organizations further conceptualizes the WEF nexus related to hydropower investments on shared rivers and the potential role of regional organizations in governing this nexus situation. The paper then introduces the cases studies and the methodologies used. The section on Results presents key findings, following by a discussion of these findings. The Conclusion presents the wider implications for nexus governance.

\section{WEF NEXUS, HPPS AND THE POTENTIAL ROLE OF REGIONAL ORGANIZATIONS}

In order to conceptualize the potential role of regional organizations in governing the WEF nexus related to hydropower investments on shared rivers, this section draws upon and brings together three strands of literatures, namely (1) on governing the WEF nexus, (2) on regime theory/neo-institutionalism in international relations, and (3) on benefit-sharing related to HPPs on shared rivers. The section on Governing the WEF Nexus Related to Hydropower on Shared Rivers discusses implications of the emerging literature on governing the WEF nexus for the case of hydropower on shared rivers. Drawing on regime theory and literature on benefit sharing, section Potential Benefits From Coordination and Nexus Governance Related to HPP on Shared Rivers asks for potential benefits from-or incentives forcoordinating WEF-nexus implications of hydropower projects across countries. Further elaborating on regime theory/neoinstitutionalism, section Regional Organizations as Coordinating Agencies? then focuses on the role of regional organizations in fostering the governance of WEF-nexus implications of hydropower projects on shared rivers.

\section{Governing the WEF Nexus Related to Hydropower on Shared Rivers}

The WEF nexus literature often bemoans a lack of coordination between relevant policy sectors and argues that there is a need to "overcome" siloed decision-making and to work across sectoral boundaries (Hoff, 2011; Leck et al., 2015; Rasul and Sharma, 2016). Many authors stress the need for cross-sector coordination and adequate multi-level governance, taking the geographical scale of the respective nexus problem into account (Leck et al., 2015; Müller et al., 2015; Weitz et al., 2017; Pahl-Wostl, in press). Others argue for flexible, adaptive and polycentric governance mechanisms for nexus governance (Gallagher et al., 2016). Hence, managing the WEF nexus is not only a matter 
of understanding interconnections (e.g., through modeling) of technology and infrastructure, but also a matter of governance (Bazilian et al., 2011; Kurian, 2017).

However, as Stein et al. (2014) argue, governance can as much be part of the solution, as it can be part of the problem. Weitz et al. (2017) thus argue that there is a need to better understand the conditions under which coordination related to the WEF nexus might come about, including the benefits that self-interested actors might derive from coordination as well as the emergence and role of coordinating agencies, but also the challenges that are likely to hinder coordination across WEF sectors and levels of governance. Based on their comprehensive evaluation of the literature on Integrative Environmental Governance they put forward that coordination may be supported by communicative (e.g., Sustainable Development strategies), organizational (e.g., working groups, coordinating agencies), and procedural (e.g., Strategic Environmental Assessments, SEA) instruments, smart policy mixes as well as the presence of meta-governance principles (e.g., transparency, accountability) and information. However, they also note that (1) negotiations usually take place among actors with unequal power, (2) cross-sector coordination may be inhibited by the transaction costs of involving all affected actors, and (3) solutions may simply lie outside the concerned nexus sectors. Recent case studies on governing the WEF nexus in developing countries also hint at these obstacles, but highlight low state capacities as well as lack of data related to natural resource use as additional barriers (Never and Stepping, forthcoming; Rodriguez-de-Francisco et al., in preparation).

When hydropower investments are made along international rivers, it is not only necessary to ensure coordination between the energy, water, environment and, possibly, agricultural sectors within the investing country, but often also with respective sectoral institutions in riparian countries and possibly with further non-state actors, if conflicts among states are to be prevented. In the international system, such cross-border, crosssector coordination relies on voluntary negotiations of the actors involved. However, it has been argued that such negotiations may be supported by interstate organizations at regional level (hereinafter "regional organizations"), such as international river basin organizations (IRBOs). For instance UNECE (2015: 5) argues that given that IRBOs “... have experience in bringing together different stakeholder[s] across a basin, they lend themselves naturally to the implementation of nexus-based management approaches in shared basins." Similarly, a draft UNEP report points out that IRBOs can be catalysts to help govern the WEF nexus as they usually work with the agricultural sector on irrigation, the energy sector on hydropower or the environment sector on wetlands (UNEP, 2014). However, the report also warns that the institutional set-up, mandate and capacity of IRBOs may vary considerably across basins, which may influence the ability of IRBOs for nexus governance. Furthermore, Scheumann and Tigrek (2015) put forward that in transboundary settings it may sometimes be easier for energy rather than for water sector institutions to resolve issues around hydropower. Hence, regional economic communities, regional energy organizations or possibly regional power pools may also play a role in nexus governance.
In the following, we argue that nexus governance related to hydropower on shared rivers takes place, if riparian countries coordinate in the design of HPPs so that interdependencies between energy, water and food security are taken into account. We assume that coordination can be expected, if it is in the (perceived) self-interest of the respective investing countries (section Potential Benefits From Coordination and Nexus Governance Related to HPP on Shared Rivers). We furthermore explore in what ways regional organizations might influence whether such coordination occurs (section Regional Organizations as Coordinating Agencies?).

\section{Potential Benefits From Coordination and Nexus Governance Related to HPP on Shared Rivers}

Regime theory in international relations theory argues that in the international system coordination and cooperation can be expected when it is in the interest of the actors involved and, in particular, when the actors involved may realize benefits from cooperation (e.g., Keohane, 1984). However, often, even where potential benefits of cooperation exist, cooperation may be inhibited by collective action dilemmas in which individual rationality leads to collectively sub-optimal outcomes (Stein, 1982). In this case, regime theory assumes that institutions-or international regimes-may play a critical role in promoting cooperation. International regimes can be understood as "implicit and explicit principles, norms, rules, and decision-making procedures around which actors' expectations converge in a given area of international relations" (Krasner, 1983). Complementary to regime theory, the literature on benefit sharing explores in greater depth opportunities for the generation of benefits of cooperation on shared rivers as well as institutional prerequisites for their realization (Sadoff and Grey, 2002; Klaphake, 2006; Dombrowsky, 2009; Scheumann et al., 2014). We use this literature to explore potential benefits from cooperation and hence a country's potential self-interest in coordination and nexus governance related to HPPs on shared rivers.

While the main purpose of HPPs is to contribute to energy security, they may negatively affect water resources, ecosystems and livelihoods, including water and food security, at the reservoir site or downstream of it. However, HPPs may also themselves be negatively impacted by upstream land and water use.

In many cases, hydropower projects on international rivers are pursued unilaterally by one riparian state. However, the literature on benefit sharing has established that it can be in the self-interest of states to engage in multilateral coordination and cooperation in order to avoid negative impacts or to generate positivesum outcomes. If self-interest is understood in a narrow sense, e.g., ignoring reputational effects, an investing state may not be concerned about negative impacts on downstream countries. However, the situation may change if the investing state is interested in maintaining general good relations with its coriparian states or if an international water treaty commits signatories to avoid significant harm (LeMarquand, 1977). 
Hence, whether negative impacts of HPPs on downstream countries and related nexus effects are taken into account also depends on how self-interest is defined. The situation is more obvious, if the HPP itself is negatively impacted by upstream countries' land and water uses. For instance, it could be conceivable that hydropower investors offer Payments for Ecosystem Services (PES) to land and water users upstream in order to reduce negative impacts on the operation of the plant (Rodriguez-de-Francisco et al., in preparation).

The literature on benefit sharing has argued that under certain conditions benefits from joint dam construction offer incentives to pursue HPPs as joint rather than unilateral investments. Such incentives to cooperate exist if: (i) cooperation will enable states to overcome economic or financial limitations to unilateral action (e.g., in the case of the Manantali dam on the Senegal River); (ii) altering the design of a dam upstream will increase aggregate net benefits (e.g., dams on the Columbia River); (iii) locating a dam upstream will increase aggregate net benefits (e.g., Lesotho-Highlands Project on the Orange-Senqu River); or (iv) if a joint dam on a border river will produce mutual benefits (e.g., Kariba Dam on the Zambezi River) (Hensengerth et al., 2012; Scheumann et al., 2014). In the case of joint investments, it is often easier than in the case of unilateral investments to take multiple benefit and cost streams for the various actors involved into account and to compensate those who lose. In fact, taking the various cost and benefit streams into account may even be necessary in order to come to an agreement. Hence, it can be assumed that joint investments are conducive toward nexus governance. However, the literature also indicates that in past projects, the effects of these joint dams on the provision of ecosystem services were not necessarily considered (Hensengerth et al., 2012). Indeed, coordination over dam projects in the above cases has occurred in the interest of maximizing electricity output, rather than in the interest of generating positive tradeoffs for water and food security. Hence, while nexus governance may be easier and more likely in the case of joint rather than unilateral investments, even joint investments do not provide a guarantee for adequate nexus governance. This raises the question to what extent nexus governance related to HPPs on shared rivers may be further fostered by regional organizations as potential coordinating agencies.

\section{Regional Organizations as Coordinating Agencies?}

When international regimes are institutionalized in a way that they take on actor quality, understood as the ability to act independently, we may speak of international organizations (Schmeier et al., 2016 with reference to Keohane, 1988). More specifically, IRBOs have been defined as "institutionalized forms of cooperation that are based on binding international agreements covering the geographically defined area of international river or lake basins characterized by principles, norms, rules and governance mechanisms" (Schmeier et al., 2016). Out of 124 potential cases, Schmeier et al. (2016) identified a total 81 IRBOs worldwide that satisfied their definition.
As argued by neo-institutionalism, a key function of international organizations is to support member states' interaction (Abbott and Snidal, 1998), and as such reduce transaction costs. Overall, the literature on international and regional organizations identifies various functions that these organizations may fulfill. It has been argued that they provide a stable negotiation forum, which may be used for (1) building trust, (2) establishing rules of engagement (e.g., supporting principles of international law and social and environmental safeguards), (3) analyzing cooperative strategies, (4) pooling or attracting financial resources, (5) sharing the benefits and costs of cooperation, (6) monitoring the implementation of agreements-and hence enforcement-and (7) managing conflicts (e.g., Schiff and Winters, 2002; Hensel et al., 2006; Linn and Pidufala, 2008; Gerlak and Schmeier, 2016).

In terms of nexus governance, in the following we argue that there may be three main avenues by which regional organization may encourage member states to take the cross-border, crosssector effects of hydropower investments into account: first, by supporting benefit-sharing arrangements, second by ensuring the application of safeguards, and third by fostering the application of principles of international water law. First, regional organizations may support the negotiation of benefit-sharing arrangements by two or more riparian states. This will mostly relate to cases in which co-riparians opt for joint investments, but could theoretically also apply to unilateral investments [e.g., such as currently discussed for the Grand Ethiopian Renaissance Dam (Tawfik and Dombrowsky, 2018)]. In this context, regional organizations may also support the self-interested coordination with upstream water and land users [as occurred during the negotiations for the Columbia River Treaty (LeMarquand, 1993)].

Second, regional organizations may support the application of international social and environmental safeguards (Abbott and Snidal, 1998). This will be easier if investments are planned jointly, but may even apply to unilateral investments. This could include a comprehensive options assessment before a decision on a particular energy generation option is taken, as recommended by the World Commission on Dams (WCD, 2000). A Strategic Environmental Assessment (SEA) "helps define key aspects related to the effects of the energy installations; evaluates a wide range of likely environmental and health impacts; compares alternatives and pros and cons; determines adaptation and mitigation measures and actions; and helps move toward increased efficiency of resources" (UNECE, 2015). Possibly, the regional organization could also carry out a "transboundary nexus assessment," as developed by UNECE (UNECE, 2015; Strasser et al., 2016). Furthermore, a regional organization may develop its own guidelines for sustainable hydropower, as did the International Commission for the Protection of the Danube River (ICPDR, 2013) and the Mekong River Commission (MRC, 2009). Once a decision on a hydropower investment is taken regional organizations may coordinate the preparation of transboundary Environmental and Social Impact Assessments (ESIAs) (UNECE, 1991; Bastmeijer and Koivurova, 2008) and Resettlement Action Plans in order to minimize and mitigate negative impacts. 
Third, IRBOs, in particular, may support the application of principles of international water law. IRBOs are usually based on basic customary principles of international water law, such as "equitable and reasonable utilization," "avoidance of significant harm," and "prior notification" (McCaffrey, 2003; Schmeier, 2013). While "significant harm" is to be avoided, according to the 1997 UN Watercourse Convention, the less severe "significant adverse effects" are to be dealt with through procedures of prior notification (see Articles 13-19). So far, 36 states have ratified the convention, and are bound by these principles (Gupta, 2016). Even if riparian countries have not ratified the Convention, we may expect that many IRBOs encourage notification processes as a customary principle of international water law (McCaffrey, 2003). However, in many cases such as the Mekong, the issue has been as to what international water law principles such as "significant harm" mean, and different basin states have applied different views, leading to differences in perception that are hard to unite (Conca et al., 2006).

Empirical research on IRBOs shows that the design, the functions and the effectiveness of IRBOs vary significantly. IRBOs differ greatly in terms of their membership, mandate and functional scope, organizational and financing structure and capacities (Dombrowsky, 2007; Schmeier, 2013; Gerlak and Schmeier, 2016). Next to contextual factors, IRBO design has been identified as an important determinant of IRBO effectiveness (Schmeier, 2013; Gerlak and Schmeier, 2016), and it is also likely to influence nexus governance. For instance, it can be assumed that it is more likely that transboundary effects are considered if all affected countries are members of the regional organization. Furthermore, it may be easier to involve various sectors if the organization has a sufficiently broad mandate and functional scope to do so. Where in place, secretariats may provide information and hence reduce uncertainty, increase transparency and lower transaction costs (Linn and Pidufala, 2008; Saruchera and Lautze, 2016), and may even serve as agenda setters by exploring technically feasible and mutually acceptable solutions (Bauer, 2006; Dombrowsky, 2007; Jinnah, 2014). Hence, in the case studies we will further explore what role the respective regional organizations played in terms of supporting benefit-sharing arrangements, ensuring the application of safeguards, and fostering the application of principles of international water law, and how these potential roles were influenced by their institutional designs (membership, functional scope und secretariat).

\section{THE CASES AND METHODOLOGY}

Our research is based on a case study approach, as the total universe of possible cases to be studied for our object of analysis is rather limited, and as it is not straightforward to establish causal relationships in the respective complex settings. Still, case studies are one approach to test whether certain theoretical assumptions are applicable in the real world (Yin, 1994). According to Gerring (2007), the case study approach is defined as an intensive study of a single unit or a small number of units (the cases). It allows some degree of inference about a larger class of similar units, although the unit under consideration is not representative and homogeneity across the sample is not possible. It also enables theoretical development based on empirical insights obtained from the field work conducted. We have selected three cases that illustrate variations of failure and success by regional organizations to manage nexus impacts of HPPs. (1) The Rusumo Falls project on the Kagera River, a tributary of the Nile, is pursued by Burundi, Rwanda, and Tanzania (Figure 1). The Nile Equatorial Lakes Subsidiary Action Program (NELSAP), a suborganization of the Nile Basin Initiative (NBI), coordinates, and the World Bank finances, the project. (2) Planned by Burundi, the Democratic Republic of Congo (DRC), and Rwanda, the Ruzizi III HPP on the Ruzizi River is being coordinated by Energie des Grands Lacs (EGL), a regional energy organization (Figure 1). There are plans to involve a private investor as part of a publicprivate partnership (PPP) supported by several development banks. (3) Laos is constructing the Xayaburi dam on the Mekong with the support of Thai investors; the investment decision was taken outside of the MRC, although Xayaburi falls under the remit of the MRC's mandate (Figure 2). These cases differ in the following aspects: first, whether hydropower is planned jointly (Ruzizi, Rusumo) or unilaterally (Xayaburi); second, whether the process is supported by an IRBO (Rusumo, Xayaburi) or a regional energy organization (Ruzizi); and, third, whether private investors are present (Ruzizi, Xayaburi) or not (Rusumo). As such, they allow for a deeper understanding of the role of IRBOs in managing WEF nexus.

All cases build on extensive field research involving qualitative semi-structured expert interviews [on expert interviews see Bogner et al. (2005)]. We found qualitative semi-structured interviews to be useful in highly politicized contexts such as presented here as they allowed to "elicit [...] tacit knowledge and subjective understandings and interpretations" (Marshall and Rossman, 2006: 53). This method further allowed for a prior elaboration of a flexible interview guideline (adaptable for different actor groups) which facilitated good comparability between interviews (Bryman, 2008). Interviewees were selected following a snowball sampling technique. Snowball sampling is a non-probability sampling technique that starts with the identification of an initial interviewee, who then provides further contacts. The procedure was repeated with additional interviewees until saturation was reached [see Kirchherr and Charles (2018) for a description and a critical review of this method in a hydropower context]. In all cases, counterpart institutions acted as important gatekeepers: they were connected to all relevant stakeholders involved in the projects and facilitated access to important interviewees.

Field work for Rusumo Falls and Ruzizi III was carried out between December 2012 and April 2013 and included a review of pertinent planning documents and 95 stakeholder interviews with representatives of regional organizations, donor representatives, members of the national negotiation teams, representatives of the government ministries or agencies involved, environmental and social experts, representatives of sub-national and local administrations, as well as representatives of the affected communities, civil society and non-governmental organizations (NGOs) in all four countries. Interviewees were 


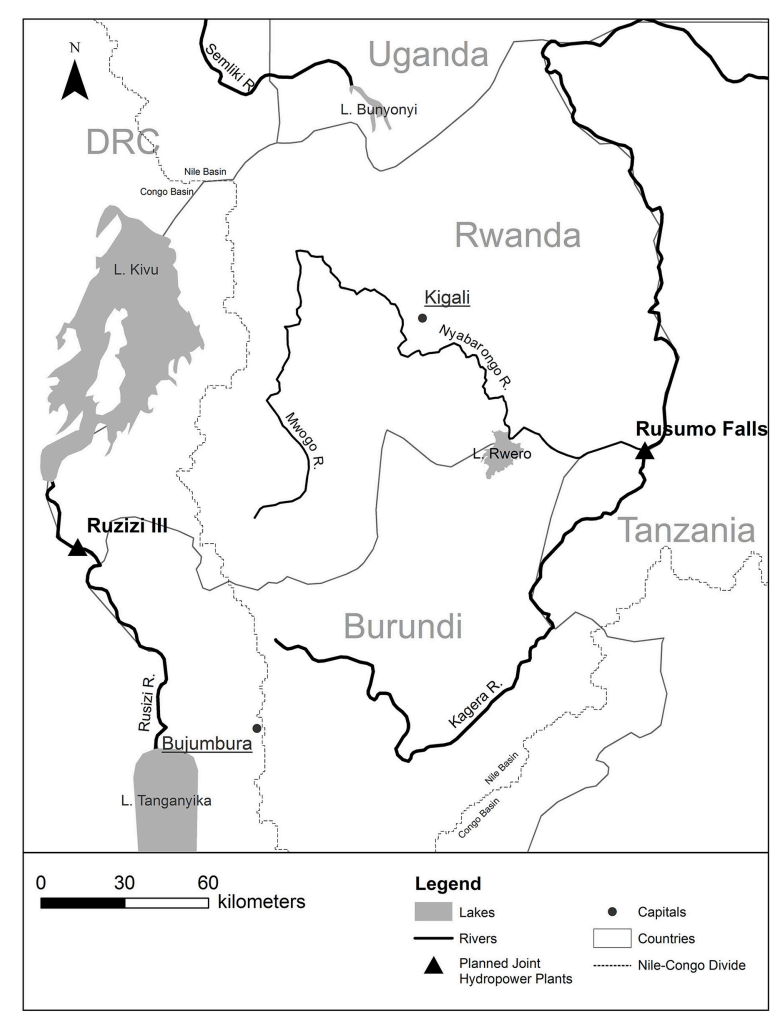

FIGURE 1 | Location of the Rusumo Falls and Ruzizi III projects, Source: Own preparation.

selected based on their involvement in the negotiation of both hydropower projects, their energy and environment sector expertise or their connection to local project-affected populations. Initial access to interviewees was provided by NELSAP for Rusumo Falls and EGL for Ruzizi III. Information was updated in 2016 and 2018 based on internet updates provided by the relevant regional and donor agencies. The interviews were transcribed, coded and analyzed using atlas.ti content analysis software.

Field work for the Xayaburi case was carried out during a four-week stay at the MRC in Laos in September 2011 and includes a review of relevant planning documents, the MRC's planning history for all Mekong mainstream dams including Xayaburi, and a total of 21 interviews with MRC personnel and NGOs. The information was updated through personal email communication with a former advisor to the MRC in August 2014, and during interviews with NGOs in Cambodia involved in Mekong basin planning in July 2015. In line with the snowball method, interviewees were selected in collaboration with international donor organizations, who provided the initial access to the MRC Secretariat and to NGOs in Vientiane. Interviewees were selected on the basis of their involvement in basin-wide planning processes, their knowledge and involvement in hydropower planning processes, the drafting of relevant policies (including EIA and resettlement), their knowledge of benefit-sharing processes, and their connection to local projectaffected communities.

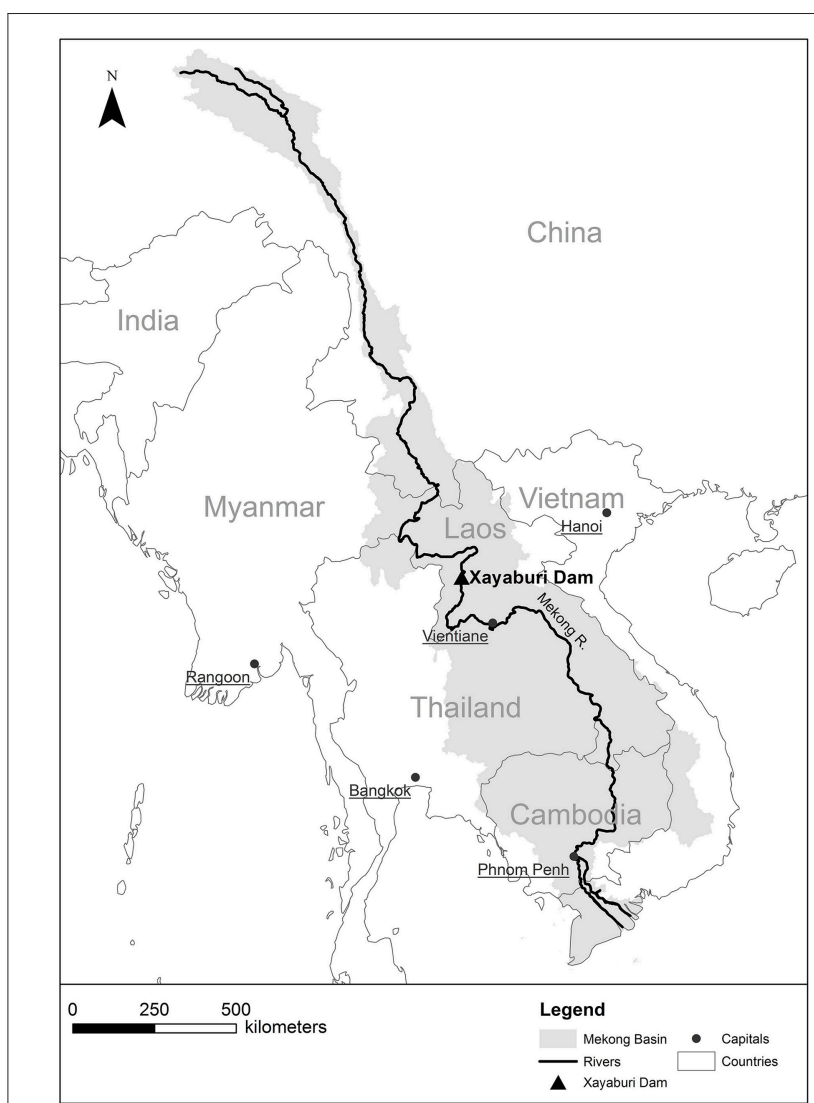

FIGURE 2 | Location of the Xayaburi dam, Source: Own preparation.

All of our interviewees were therefore considered experts, as they possessed specific technical, process, or interpretative knowledge in fields related to hydropower planning processes. Their knowledge constitutes not only specialized expertise, but it is in large parts also practical and action-oriented knowledge which intermingles with subjective interpretations (Bogner et al., 2005). This in turns lends itself to a qualitative analysis as advanced here.

The data gathered in the semi-structured interviews was analyzed with the help of qualitative content analysis. Qualitative content analysis is an empirical, methodologically controlled approach of analyzing large amounts of data linked to fixed/recorded communication (Mayring, 2000). In this case it refers to the transcribed interviews. The method rests upon a rule-based approach and is based on the assumption that the content of the interview situation, e.g., the perceptions of the interviewed experts, has to be revealed by interpretation (Mayring, 2000).

The coding of the transcribed interviews was the essential part of our qualitative content analysis. As we pursued a theorybased research design for our empirical data gathering, we were necessarily following the path of deductive category/code development. Thus, based on our understanding of the theoretical framework, we formulated definitions of relevant concepts and attributed coding rules and examples which were 
summarized in a coding manual (Mayring, 2000). Although a pure ex ante formulation of codes might be theoretically possible, we allowed for the development of predefined categories as well as inductive code definition based on the transcribed interviews themselves. The interpretation of data was thus an iterative process in which feedback loops allowed our research to be sufficiently open and at the same time adaptable to new, unexpected findings (Gläser and Laudel, 2009). In the Ruzizi and Rusumo cases, transcription and coding was done digitally and supported by $\mathrm{f} 4$ and atlas.ti content analysis software. In the Xayaburi case, coding proceeded as above but was done manually, following the recommendations by Bazeley (2007) for small-scale studies [for a debate on manual vs. electronic coding of qualitative interviews see Basit (2003)].

The African cases were analyzed by Ines Dombrowsky at the German Development Institute/Deutsches Institut für Entwicklungspolitik (DIE). The research design and methodology were peer reviewed by an expert group and presented and discussed in a two-hour public meeting at DIE to ensure compliance with the Guidelines on Safeguarding Good Scientific Practice and Preventing Scientific Misconduct of DIE, and the Proposals for Safeguarding Good Scientific Practice by the Deutsche Forschungsgemeinschaft/German Research Foundation (DFG). According to these institutional and national guidelines and regulations, an approval by an Ethics Committee was not required. In addition, for research in Rwanda an exposé was presented to the Rwandan Ministry of Science upon which the Rwandan government granted the research permit.

The case study on the Xayaburi dam was carried out by Oliver Hensengerth, who was employed at the University of Southampton during the time of field research. The project underwent the standard approval procedures of the University of Southampton following the funding decision by the British Academy, and the project was approved as part of this process, which is designed to ensure compliance of all research projects with the Ethics Policy of the University of Southampton.

In all three cases, given the political sensitivity of the research and the (partly) authoritarian political context in which the research took place, interviewees were not asked to sign consent forms. Instead, all subjects gave verbal informed consent to the use of anonymized statements from the interviews for scientific purposes.

\section{RESULTS}

The following sub-sections scrutinize transboundary nexus governance in each case by analyzing the roles the respective regional organizations played in terms of supporting benefitsharing arrangements, ensuring the application of safeguards, and fostering the application of principles of international water law, and how these potential roles were influenced by their institutional designs, in particular their membership, functional scope and the presence of a secretariat.

\section{Rusumo Falls HPP}

The Rusumo Falls HPP will be an 80 MW run-of-river plant on the Kagera River at the border between Rwanda and Tanzania (see Figure 1). While planning goes back to the 1980s in the context of the then existing Kagera Basin Organization (Rangeley et al., 1994), Burundi, Rwanda and Tanzania resumed preparation in 2006 in the context of the Nile Equatorial Lakes Subsidiary Action Program (NELSAP). NELSAP is an investment program of the Nile Basin Initiative (NBI) which includes all Nile riparian countries in the Equatorial Lakes region plus Sudan and Egypt as downstream riparians. The NBI de facto performs the functions of an IRBO and is recognized as such (Schmeier et al., 2016), even if a ratified international legal agreement is outstanding. The functional scope of NBI and NELSAP is broad and includes water, energy, and environmental issues. The planning of Rusumo Falls was taken forward by representatives of the energy administrations of the three participating countries, supported by the NELSAP Coordination Unit (CU) in Kigali as a secretariat.

Rusumo Falls is a trilateral joint investment based on a benefitsharing arrangement (Dombrowsky et al., 2014). Given that the HPP will be located at the border between Rwanda and Tanzania, the two countries had to cooperate to build a HPP. However, interestingly upstream Burundi participates in the project as an equal partner. According to our interviews, Burundi was included for at least two reasons. First, it had already been part of the planning for Rusumo Falls in the context of the Kagera Basin Organization (Int. 5, 8, 87). Second, as a reservoir project the reservoir would have inundated Burundian territory (Int. $5,7,19,41)$. The power generated is envisioned to be equally shared among the three countries. The HPP will be publicly owned, but privately managed. The Rusumo Power Company Limited, co-owned by the three governments involved, was registered in March 2013. Financial closure with the World Bank was reached in August 2013. ${ }^{1}$ The World Bank's International Development Association provided USD 113.3 million as loans or grants to each country for its equity in the Rusumo Power Company. The compensation of project-affected populations took place in 2015. The contract with the construction firm was signed in November 2016 and construction started in March 2017. ${ }^{2}$ Rusumo Falls will be connected to the East African Power Pool.

In 2002, energy experts from the Nile Equatorial Lakes countries decided to carry out an SEA of energy options, given that it was a requirement of the World Bank before selecting specific projects. The SEA presented in 2005 identified Rusumo Falls HPP (as well as Ruzizi III) as one of the five most realistic medium-term power options (NBI, 2005). The SEA acknowledged that Rusumo Falls was comparatively advanced in terms of technical preparation, but identified potential social and environmental impacts as drawbacks and recommended further assessments. Overall, the SEA signaled a preference for hydropower options due to the expected high cost and small size of solar energy,

\footnotetext{
${ }^{1}$ http://nelsap.nilebasin.org/attachments/article/34/Rusumo\%20Factsheet__ENGLISH.pdf, retrieved 19 July 2016.

${ }^{2}$ http://www.nilebasin.org/index.php/new-and-events/133-construction-ofrusumo-falls-hydroelectric-project-to-start-30-march-2017, retrieved 2 July 2018.
} 
or lack of identified resources for wind or geothermal energy.

In 2006, Rwanda, Burundi and Tanzania signed a Joint Project Development Agreement for Rusumo Falls. A consultant was selected to carry out a feasibility study, including an ESIA in 2007 and 2008 (SNC Lavalin International, 2008). However, it turned out that for an in-depth ESIA, procedures had to be harmonized, and a new topographical mapping, a land use study and a household survey had to be carried out (SNC Lavalin International, 2012). The countries requested the consultant to do so for the so-called "full development scheme" in order to maximize hydropower production (SNC Lavalin International, 2012). In May 2011, the consultant indicated that 17,450 households would be affected. The countries therefore decided to pursue a smaller reservoir, the "intermediate development scheme." This still resulted in 7,330 affected households. Hence, in 2012, the countries decided to go for a run-of-river scheme [Interview (Int.) 57]. Since the World Bank required a change of consultant due to corruption charges, the final results were presented in March 2013. For the run-of-river scheme, the capacity of the plant had to be reduced from 90 to $80 \mathrm{MW}$, while the number of affected households was reduced from 17,450 to 669 (ARTELIA, 2013). Of these, a total of 178 households and business units had to be resettled. The project's environmental impacts were considered moderate. The project would mainly affect biological diversity in the Rusumo Falls spray zone and interrupt the river's ecological flow on a stretch of 500 meters. Therefore, the ESIA recommended that the spray zone be equipped with an artificial spray system and a minimum environmental flow of 10\% (ARTELIA, 2013; Int. 56). In terms of negative effects on the HPP, it is expected that the reservoir will be moderately affected by sediment inflows (ARTELIA, 2013). Hence, the ESIA recommended a sediment transport study to be performed before start of construction and to potentially adapt the design to minimize risk (ARTELIA, 2013). The ESIA was carried out according to the World Bank safeguard policies and national laws. In order to ensure that the ESIA also fulfills the respective countries' national laws, upon a World Bank request, the environmental agencies of three countries also provided clearance certificates for the HPP. ${ }^{3}$ In order to comply with international water law principles, NELSAP sent a riparian notification to the Nile riparian countries downstream in November 2012 and all necessary "no objection" notifications were received (Int. 57).

Hence, while the energy ministers had initially insisted on maximizing energy generation, in the end the inclusive inter-state approach and the ESIA-induced change of scheme minimized negative impacts on the water and food security of affected communities in the three participating countries. However, the planning process could have been accelerated, had the countries decided to pursue a run-of-river HPP from the beginning. As one country representative stated: "Of course it has taken time because we wanted this project really to be a big project, to be

${ }^{3}$ http://nelsap.nilebasin.org/attachments/article/34/Rusumo\%20Factsheet_ _ENGLISH.pdf,retrieved19July2016. implemented at full capacity, but because of the environmental and social impact, we really had to reduce our ambitions" (Int. 95).

\section{Ruzizi III HPP}

The 147 Megawatt Ruzizi III run-of-river HPP to be located on the Ruzizi River on the border between Rwanda and DRC (see Figure 1), is jointly planned by Burundi, the DRC and Rwanda in the context of Energie des Grands Lacs (EGL), a regional energy sub-organization of the Communauté Économique des Pays des Grands Lacs (CEPGL). EGL consists of a General Assembly of the Ministers of Energy of the three countries, an Institutional Meeting of Experts, a board of Account Auditors and the Managing Committee. ${ }^{4}$ EGL holds an office (the secretariat) in Bujumbura directed by the Managing Committee and with staff drawn from the three countries in roughly equal proportion. The purpose of EGL is regional energy planning. ${ }^{5}$ According to Rangeley et al. (1994: 11): "EGL may be seen as an RBO only in that, through its parent organization CEPGL, it is responsible, among other things, for hydro-electric power development on the Ruzizi river linking Lake Kivu to Lake Tanganyika. Beyond that, it is a regional energy planning organization." For the negotiation of the Ruzizi III project, each country established a negotiation team. The planning process is coordinated by the EGL office. According to our interviews, downstream Burundi is included, as it is an equal partner in EGL and as the three countries already cooperated in the development and construction of the Ruzizi II HPP under the auspices of EGL (Int. $1,2,5,6,8,47,87,89,96)$. It is also included as it could potentially be affected by the project (Int. 5, 7, 19, 41).

Ruzizi III is conceived as a public-private joint venture, in which the investor will have the majority and the countries equal minority shares supported by donor soft loans. Each country is supposed to have access to one third of the energy produced, and hence, similar to Rusumo Falls, the HPP is based on a regional benefit-sharing arrangement (Dombrowsky et al., 2014). A pre-feasibility study was prepared in 1991 (CEPGL, 2012). In-depth planning started in 2007 after conflicts in the region had calmed down. Project preparation is supported by the European Investment Bank, the German KfW Development Bank, the African Development Bank, the Agence française de développement, the European Union and the World Bank. ${ }^{6}$ Negotiations between the then preferred investor, Sithe Global and Industrial Power Services (IPS, Kenya), and the three countries started in October 2012. Total costs were estimated at USD 625 million, and the African Development Bank was first to commit a total of USD 138 million of loans and grants for

\footnotetext{
${ }^{4}$ http://www.egl-grandslacs.org/index.php/en/about-egl/egl-bodies, retrieved 2 July 2018.

${ }^{5} \mathrm{http}: / /$ www.egl-grandslacs.org/index.php/en/about-egl/mission-and-objectives, retrieved 2 July 2018.

${ }^{6} \mathrm{http} / / /$ www.afdb.org/en/news-and-events/article/afdb-approves-regionalhydropower-ppp-to-increase-electricity-supply-and-integration-in-burundidrc-rwanda-15255/, retrieved 20 July 2016.
} 
the construction of Ruzizi III in December 2015. ${ }^{7}$ Signature of the Project Agreements between the three countries and a new investor consortium consisting of IPS and SN Power (Norway) had last been envisioned for May 2018. However, the signature could not be realized as no final consensus could be reached on three outstanding issues, including on avoiding that potential surplus construction would be reflected in the tariff. ${ }^{8}$ Instead the three countries signed a Declaration reinforcing their intention to proceed with the project. Like Rusumo Falls, Ruzizi III is supposed be connected to the East African Power Pool.

In terms of social and environmental safeguards, as mentioned above, Ruzizi III was identified as a medium-term priority energy investment in NELSAP's SEA of 2005. In the SEA, this option had the best rank in the economic, financial and environmental categories, as no resettlement was expected (NBI, 2005). The EGL office coordinated the preparation of the ESIA, which was financed by the European Investment Bank. In 2012, a pre-final ESIA was presented (SOFRECO et al., 2012). For the ESIA, SOFRECO conducted a household survey and various stakeholder consultation workshops. The ESIA found that 648 households would be affected, and eight to nine would have to be resettled. Due to its potential affectedness, Burundi is supposed to participate equally in the Local Community Development Plan. Interviewees also argued that given that all three countries will benefit from the electricity produced, communities in the project areas of all three respective countries should benefit too (Int. 34, 37, 38, 44, 54, 55, 66, 71, 78). The environmental impacts of the HPP were considered moderate: next to the existing Ruzizi I and II HPPs, Ruzizi III would be a further obstacle for the Ripon barbell fish. Furthermore, Ruzizi III would interrupt the ecological flow on a stretch of $4.3 \mathrm{~km}$. Therefore, the migration of fish shall be secured by the installation of fish passes and a minimum ecological flow of $8 \%$ is to be maintained (SOFRECO et al., 2012). The European Investment Bank required the countries to carry out the ESIA according to World Bank safeguards as well as respective national laws. In case of divergence between national laws and World Bank policies, the higher standard was applied (SOFRECO et al., 2012). In March 2016 the Social and Environmental procedure manual was validated. ${ }^{9}$ Hence, in this case, donor safeguards also played a role, and their application was facilitated by the regional organization EGL. However, the pre-final ESIA needs to be validated by the private investor.

Given that EGL is a regional energy organization, international law principles are not anchored in its statutes. However, prior notification was also not required as all affected riparian states are involved in project preparation.

Quite significantly, given that the functional scope of EGL does not include land and water uses, EGL as a secretariat even

\footnotetext{
${ }^{7}$ http://www.afdb.org/en/news-and-events/article/afdb-approves-ruzizi-iiihydropower-plant- project-bringing-green-energy-to-burundi-drc-and-rwanda15275/, retrieved 20 July 2016.

${ }^{8} \mathrm{http}: / /$ www.egl-grandslacs.org/index.php/fr/publications/actualites/89declaration-de-kinshasa-sur-le-projet-ruzizi-iii, retrieved 2 July 2018.

${ }^{9} \mathrm{http}: / / \mathrm{www} . \mathrm{afdb}$.org/en/news- and-events/article/afdb-approves-regionalhydropower-ppp-to-increase-electricity-supply-and-integration-in-burundidrc-rwanda-15255/, retrieved 20 July 2016.
}

facilitated the set-up of an IRBO to promote the sustainable management of the Lake Kivu and Ruzizi River Basin, the Basin Authority of the Lake Kivu and the Ruzizi River (Autorité du Bassin du Lac Kivu et de la Rivière de Rusizi, ABAKIR). This was done given that the Ruzizi valley is very steep, and human-induced and natural erosion (as well as litter) may provide significant threats to the project (SOFRECO et al., 2012). The International Convention on the Integrated Management of Water Resources of the Lake Kivu and Ruzizi River Basin (ABAKIR, 2011) was signed by the Water Ministers of the three states in July 2011. Pending ratification through the heads of state, an interim institutional arrangement was set up at the premises of CEPGL in January 2013, financed by the European Development Fund (Int. 17, 62). ABAKIR is supposed to provide a basis for a better use of shared waters in the basin and therefore mitigate the risk of lower energy output due to detrimental upstream water usage. In addition to ABAKIR, a coordination center will be put in place by the three countries to coordinate the use of the Ruzizi River across the Ruzizi I, Ruzizi II and Ruzizi III HPPs (Int. 2). Furthermore, the ESIA proposed to set up a 5 years anti-erosion program in the order of USD 1.7 million (SOFRECO et al., 2012). In this context, the consultants also suggest that the project developer considers setting up a PES scheme in the Ruzizi Valley.

\section{Xayaburi HPP}

The Xayaburi HPP is a 1285 Megawatt HPP built by Laos on the mainstream of the Mekong, financed by private Thai banks and constructed by the Thai construction company $\mathrm{Ch}$. Karnchang. Laos plans to export $95 \%$ of the electricity produced to Thailand (Middleton and Dore, 2015). Laos along with Thailand, Cambodia and Vietnam is a member of the MRC. Upstream China and Myanmar are not members and have observer status. China has been collaborating with the MRC during dry season flow, but has refused to share further data.

The MRC has a wide-ranging functional scope. Article 1 of the 1995 Agreement on the Cooperation for the Sustainable Development of the Mekong River Basin (henceforth: 1995 Agreement) commits members to "cooperate in all fields of sustainable development, utilization, management and conservation" including hydropower, fisheries, navigation, and flood control. The principal tool for this is the Basin Development Plan (MRC, 2016a) which develops a joint planning approach, including an equitable distribution of risks and benefits between all member states. This joint planning function is carried out by the MRC's Secretariat on behalf of member states, who are represented in the Council (heads of government) and the Joint Committee (sector ministries) and who determine the Secretariat's work plan (1995 Agreement, Chapter IV). The Basin Development Plan is mutually agreed by member states. To implement it, the MRC has set out a number of guidelines and procedures. With relevance to mainstream hydropower dams, this includes a 5-volume Knowledge Base on Benefit Sharing (MRC, 2011), the Procedures for Prior Notification, Consultation and Agreement (PNPCA) (1995 Agreement, Article 5; (MRC, 2016b), and the Preliminary Design Guidance for Proposed Mainstream Dams in the Lower 
Mekong Basin (MRC, 2009). The MRC also applies principles of international water law, notably the principles of reasonable and equitable utilization, and no harm (1995 Mekong Agreements, Articles 5 and 7) and has operationalized the principle of prior notification in the PNPCA. The focus on hydropower is important as Laos and Cambodia are planning a total of eleven dams on the Mekong mainstream, of which nine are to be located in Laos and two in Cambodia. This is in addition to the upstream dams built or planned by China. The first of the eleven dams in the Lower Mekong is the Xayaburi dam.

Although as a mainstream dam Xayaburi is subject to MRC procedures and guidelines, Laos initiated the project unilaterally. In 2007, Laos concluded a Memorandum of Understanding (MoU) with Ch. Karnchang to study the feasibility of the project; in 2008 the two parties signed a Project Development Agreement. In 2010 Thai engineering consulting company TEAM completed the feasibility study and the ESIA. However, the ESIA assessed impacts only ten kilometers downstream from the dam site. Hence, transboundary effects with respect to sediment transport and fisheries, and implications for food security downstream were not studied.

Still in 2010, Laos and the Electricity Generating Authority of Thailand (EGAT) signed a MoU for a Power Purchase Agreement despite ambiguity over the status of the dam (Matthews, 2012); and Laos and Ch. Karnchang signed the Engineering, Procurement and Construction contract (Hensengerth, 2015). Following the completion of these processes, Laos submitted the project documents to the MRC, which started the MRC's first ever PNCPA process. In these processes, the politics of the Thai electricity sector played an important role. In particular, the monopoly position and profit structure of the Thai state-owned electricity utility EGAT, private sector profit interests, and civil society opposition against domestic HPPs are strong drivers for the Thai government and private actors to support hydropower development in Laos, with an eye to importing the produced energy (Matthews, 2012).

The PNPCA process lasted for six months, from October 2010 to April 2011 and was held at Joint Committee level. It ended without agreement, with downstream Vietnam and Cambodia citing a threat to their food security, a claim that Laos rejected. The issue was moved up to Council level, but still members were unable to find a compromise. During the Council meeting in December 2011, Council members decided to commission a study to further explore potential transboundary impacts of mainstream hydropower dams (the so-called Council Study). Meanwhile, Cambodia and Vietnam found support for their concerns in a transboundary SEA study for all planned Mekong mainstream dams, commissioned by the MRC in 2009, funded by MRC donors, and conducted by Australian environmental consulting firm ICEM. The SEA suggested a severe lack of data on transboundary impacts and therefore a moratorium on dambuilding for ten years to allow the generation of reliable data (ICEM, 2010). In contrast to the TEAM ESIA study, the SEA considered cumulative impacts of the eleven mainstream dams (Suhardiman et al., 2015). Again, Laos rejected that Xayaburi would produce any downstream impacts. Yet, facing a public backlash from downstream countries, international donors as well as regional and international NGOs and media outlets, Laos commissioned Swiss-Finnish consultancy Pöyry to conduct a study on whether Laos complied with the 1995 Agreement, the PNPCA, and the Preliminary Design Guidance for Proposed Mainstream Dams in the Lower Mekong Basin. This so-called Compliance Study, published in 2011, found Laos in compliance but suggested alterations to the dam design to allow fish passage and sediment flush (Pöyry, 2011). While Laos subsequently altered the dam design accordingly, it did not alleviate concerns by Vietnam, Cambodia and NGOs who insisted on implementing the moratorium proposed by the SEA. Citing its compliance with MRC guidelines and procedures, and insulated from international pressure by private Thai finance, Laos continued planning for the dam and held the ground breaking ceremony in November 2012.

The Council Study was published in 2017. It concludes that if mainstream dams are not realized, the Lower Mekong Basin would lose almost $60 \%$ of economic benefits in the power generation sector. At the same time, however, "nearly $25 \%$ of the hydropower gains would be lost in the fisheries sectors" (MRC, 2017b: 6, 52). In the absence of benefit-sharing mechanisms and coordination with China and Myanmar, positive and negative impacts will be unevenly distributed between upstream and downstream countries, but also between poor and richer population groups, with significant impacts on food security to be felt particularly in Laos and Cambodia (MRC, 2017a: 2-4, 6-7). The Council Study therefore confirmed previous studies suggesting a strong impact on food security due to the impact on fisheries (Smajgl et al., 2015; Pittock et al., 2016). Yet, regardless of the 2011 Council decision to conduct a multi-year study, Laos continued with dam-planning: in 2014 it notified the MRC of its decision to start construction of the Don Sahong dam. Indeed, Fawthrop ${ }^{10}$ argued that " $[\mathrm{w}]$ ork is moving forward faster than the completion of scientific studies needed to provide the evidence of 'significant harm.' " And in November 2016, Laos notified the MRC of its intention to start construction of the Pak Beng HPP. ${ }^{11}$

\section{DISCUSSION}

This paper asked how regional organizations may influence nexus governance related to hydropower projects on international rivers. We posited that countries investing in hydropower can be expected to coordinate regarding the HPP's energy, food and water security impacts if coordination is in their perceived self-interest. Regional organizations may furthermore foster transboundary nexus governance by supporting benefitsharing arrangements, ensuring the application of safeguards, and fostering the application of principles of international water law. We assumed that these potential roles were influenced by the organization's institutional designs, including an inclusive membership structure, a sufficiently broad functional scope

\footnotetext{
${ }^{10}$ https://thediplomat.com/2014/04/mekong-summit-struggles-to-haltdevastating-dams/, retrieved 5 July 2018.

${ }^{11}$ Further details on the Don Sahong and Pak Beng PNPCA can be found on the MRC's PNPCA pages at http://www.mrcmekong.org/topics/pnpca-priorconsultation/, retrieved 5 July 2018.
} 
und the presence of a secretariat. Overall, the cases show that there can be fundamental differences in the way cross-border, cross-sector coordination related to hydropower investments does or does not take place and the role regional organizations do or do not play in this.

With respect to the investing state's self-interest to coordinate across countries and sectors, fundamental differences exist between the African and the Mekong cases. The two African HPPs are investments on border rivers, and hence required coordination at least among the two border states. Still, quite significantly in both cases, Burundi as potentially affected third country was included as an equal partner which fully participates in the benefit-sharing scheme. In the Rusumo Falls case, WEF nexus governance furthermore took place in so far as the dam design was changed from a reservoir to a run-of-river project. In the Ruzizi III case, the set up of ABAKIR as IRBO can be considered as an additional element of nexus governance. In contrast, Xayaburi is a quasi-unilateral investment by Laos (albeit with Thai support) on a transboundary river. In this case Laos (and Thailand) decided to go ahead with the project despite potential negative effects on downstream Cambodia and Vietnam, even if in the end some modifications in dam design, and hence arguably some limited nexus governance, took place. However, the unilateral investment happened even despite Lao and Thai membership in the MRC and elaborate MRC provisions on joint planning and benefit sharing related to mainstream Mekong dams. Hence, in line with literature on benefit sharing, the cases show that nexus governance may be easier in the case of joint rather than unilateral investments. Furthermore, in the two African cases, arguably not least due to donor requirements, more attention was given to social and environmental impacts that in some earlier joint dam projects studied by Hensengerth et al. (2012).

In terms of the HPP itself being negatively impacted by upstream countries' land and water uses, the Ruzizi case is illustrative. The set-up of an IRBO for Lake Kivu and the Ruzizi River (ABAKIR) and the proposed PES schemes demonstrate that it can be in the self-interest of those who plan HPPs to coordinate with-and even to set up-an IRBO in order to reduce negative effects of upstream water and land uses on the HPP.

With respect to the role of the regional organizations in supporting benefit-sharing arrangements, in the African joint investments NELSAP and EGL provide the platforms for joint project preparation and the respective secretariats are supporting the planning process in several ways, even if both processes are taking much more time than originally envisioned and even if it is still uncertain whether a final agreement will be reached for Ruzizi III. In contrast, while the MRC Secretariat sought to influence the decision-making process related to the Xayaburi dam, it was in a fundamentally different position, having no implementation mechanism to force countries to provide mutually beneficial solutions. Hence, Xayaburi points to the limits of IRBOs to coordinate HPP investments, if member states are unwilling to pursue respective investments in the framework of the regional organization. It also shows that the scale at which HPP investment decisions are taken may not correspond to the basin level (Matthews, 2012; Hensengerth, 2015), which may limit the influence of IRBOs.

In terms of the role of the regional organizations in ensuring the application of safeguards, in all three cases regional organizations initiated SEAs with the support of donors. The two African HPPs were identified in an SEA of power options coordinated by an IRBO (NELSAP). However, the preparation of this SEA was driven by World Bank policies, so it is unclear whether this would have taken place in the absence of donors. In the Xayaburi case, the MRC Secretariat initiated a donor-supported SEA after Laos had signed a MoU with Ch. Karnchang. While the SEA recommended a ten-year moratorium on construction, and further studies, Laos did not take up this recommendation, illustrating the limits of the MRC and of the SEA as a procedural instrument vis-à-vis private-sectorsupported investments. Suhardiman et al. (2015: 199) point out that the MRC Secretariat still used the SEA "as a way of providing political space and opening the discussions on dams to a wider public" and of informing the PNPCA process. Hence, the MRC Secretariat used the SEA to influence the discourse and Laos's dam design to a certain extent in a situation where the limits of its agenda-setting power became obvious.

With respect to the role of regional organizations in the preparation of ESIAs, the juxtaposition of the two African and the Mekong cases also illustrate stark differences, depending on whether the investments are undertaken jointly or unilaterally. The African joint investments coordinated through regional organizations made an ESIA covering all states involved obvious. However, similar to the SEA, in both cases the ESIAs needed to satisfy World Bank requirements. In contrast, in the Xayaburi case, Laos did not prepare a transboundary ESIA and resisted doing so even after repeated requests from Vietnam, Cambodia, the MRC Secretariat and donors. Hence, regional organizations are more likely to be in a position to coordinate ESIAs in the case of joint rather than unilateral investments.

In terms of the role of regional organizations supporting the application of international water law in general and prior notification in particular, the cases show that the two IRBOs, NELSAP and MRC, promoted notification procedures, albeit with differing success. In the Rusumo case, the downstream countries beyond Lake Victoria provided no objections without further complications. It is worthwhile noting that impacts can be expected to be minimal since HPP-induced flow variations of the Kagera River would be buffered by Lake Victoria. Furthermore, as a run-of-river project, no consumptive uses and low evaporation losses are expected. Still, Egypt's no objection reflected a shift of attitude, as Egypt used to observe Rwandan water uses carefully before the NBI was established (Int. 57). In the Xayaburi case, the application of prior notification through the PNPCA process did not lead to constructive consultations. While downstream countries, donors and NGOs used the MRC as a focal point for their protest (Hensengerth, 2015), the PNPCA process certainly remains unsatisfactory. The case also shows that the international legal principles of reasonable and equitable utilization and avoidance of significant harm were understood differently by member states, leading to a 
rejection or to different interpretations of underlying data. Donors subsequently proposed a review of the implementation of the PNPCA provisions (Hensengerth, 2015). In contrast to the IRBOs, EGL as regional energy organization did not apply notification procedures. However, they were unnecessary in this case as all potentially affected riparian countries were part of the investment, suggesting that membership matters in this regard. Hence, while an advantage of IRBOs may be the application of principles of international water law, the Xayaburi case also shows that this may shift the conflict to one around the interpretation of the respective principles.

Therefore, while regional organization may support benefitsharing arrangements and the application of environmental and social safeguards and international law principles, their influence also depends on the willingness of the member states and investors to abide by the organization's rules. This, however, is not only the case for nexus governance but a general challenge in international relations and therefore also for regional organizations.

We furthermore assumed that the design of regional organizations, including a broad functional scope, an inclusive membership and the existence of a coordinating secretariat matter in promoting nexus governance. With respect to membership, the inclusive institutional arrangements in the cases of Rusumo Falls and Ruzizi III ensured that potential negative impacts on third countries (in both cases Burundi) were considered and that Burundi would even equally benefit from the respective HPPs. In the Mekong case, the fact that China and Myanmar only have observer status in the MRC limits MRC members' coordination with upstream water users. However, it should also be noted that Laos and Thailand went ahead with Xayaburi despite their respective membership in the MRC. This implies that while joint membership may promote coordination, it cannot be considered a sufficient condition for nexus governance.

In terms of functional scope, in the case of NELSAP, coordination of energy, water and land issues is within the mandate of NELSAP. Still, this did not prevent the energy experts for a long time from pursuing a reservoir project in order to maximize hydropower generation, although they finally changed the scheme once the resettlement figures were provided. In the case of Ruzizi III, EGL's functional scope was considered too narrow to deal with land and water uses upstream. Therefore, given the significant threats to the HPP by erosion, EGL even supported the set-up of ABAKIR as IRBO for Lake Kivu and the Ruzizi Basin, which however, still has to demonstrate its effectiveness. In that sense, a narrow functional scope did not prevent nexus governance. In the Mekong case, the MRC has an encompassing coordinating role for the sustainable development of the Mekong basin. The MRC has formulated rules for basin development, to which member states are bound. The MRC would therefore be ideally placed to consider WEF nexus and has even initiated WEF nexus dialogues (Middleton et al., 2015; Lebel and Lebel, 2018). However, as discussed above, the MRC could not prevent Laos from generating financial resources outside of the MRC and the organization's donor framework to become financially independent of any multilateral financing arrangements and from any pressure emerging from such arrangements-in sharp contrast to the African case studies. Hence, our assumption that it may be easier to involve various sectors if the organization has a sufficiently broad mandate and functional scope to do so, is not directly supported by the cases studied.

In the Rusumo Falls and Ruzizi cases, the respective secretariats played an important role in coordinating the planning and the negotiation processes. In the case of Rusumo Falls, the ESIA coordinated by NELSAP eventually led to the change of the HPP design. In the case of Ruzizi III, EGL facilitated the set up of ABAKIR as IRBO. In contrast, while in the Xayaburi case the MRC Secretariat became a focal point of the protests of downstream countries, donors and NGOs, it was not in a position to enforce its comprehensive planning procedures for mainstream dams, showing that the influence of the secretariat to set the agenda may be limited and hinges upon the willingness and compliance by its member states.

Beyond our analytical framework, the analysis shows that the effectiveness of regional organizations in fostering nexus governance is also influenced by the availability of data as well as the presence of donors and private investors. All cases show that the assessment of impacts and nexus governance is data intensive and that the lack of good data or a refusal to generate the respective data may be a hindering factor. In the Mekong case, gaining a joint understanding of impacts turned out to be difficult and Laos did not accept the ten-year moratorium suggested in the SEA to improve the scientific basis for dam planning. In the Rusumo Falls case, it took three additional years of study until an ESIA that satisfied donor demands was presented. The fact that the scientific basis for environmental impact assessments in Africa's Great Lakes region was limited was also supported by the interviews. While one group of interview respondents reiterated findings from the ESIAs that the environmental impacts of Ruzizi III and Rusumo Falls HPPs would be limited (e.g., Int. 1, 24, 56), one independent local environmental expert believed that the scope and quality of the environmental impact assessments for Rusumo Falls and Ruzizi III were inadequate (Int. 23). Doubt in the quality of the ESIA was also supported by negative experiences with other development projects (Int. $23,64)$. Furthermore, several interlocutors stated that they were insufficiently informed about environmental impacts and lacked knowledge (e.g., Int. 68).

The cases also illustrate that besides regional organizations, the presence or absence of other actors, including donors and the private sector, plays a crucial role-and maybe a more important role than the regional organizations themselves. The Xayaburi case illustrates that access to private sector capital may change the power position by and enable unilateral action of countries which, due to lack of access to financial and technical resources, were previously in a weak negotiating position (Hensengerth, 2015). But also the Thai utility EGAT and the Thai government played important roles in moving forward with the Xayaburi dam by concluding the power purchase agreement and by allowing Thai private banks to provide the loans despite the ambiguities in the PNPCA process. In the Ruzizi case, due to 
the relative economic weakness of the countries, donors are still involved next to the private investor. In this case it is still open whether a final deal will be reached, also given that the private investor is in a strong negotiation position vis-à-vis the countries involved. If the public-private joint venture comes about, the application of environmental and social safeguards will also depend on their uptake by the private investor. In contrast, Rusumo Falls is entirely donor funded. According to one interviewee, the World Bank wanted Rusumo Falls to be a "pilot" for sustainable hydropower after its reengagement with the sector (Int. 3). Still, even the World Bank could not prevent the countries from pursuing the reservoir project in the first place.

Last but not least, the Ruzizi case shows that besides IRBOs, as usually argued in the literature, also regional energy organizations may play a role in nexus governance [see also Scheumann and Tigrek (2015) for the Coruh River shared by Georgia and Turkey]. While this paper has provided first insights into potential strengths and weaknesses of both types of organizations in nexus governance, this could still be studied more systematically.

\section{CONCLUDING REMARKS}

This paper sought to contribute to the evolving literature on governing the WEF nexus by analyzing the case of hydropower investments on shared rivers and the role that regional organizations may play in governing nexus impacts. In line with Weitz et al. (2017), the article showed that under certain conditions self-interested actors might derive benefits from coordination and from governing WEF nexus impacts and that this might be promoted by coordinating agencies and procedural instruments, such as SEAs and ESIAs. This pertains in particular to the African cases studied, where hydropower investments on border rivers required coordination among the border states, where the existence of regional organizations facilitated the inclusion of Burundi as a further affected country, and where donors requested the application of World Bank environmental and social safeguards. In these cases, regional organizations supported benefit-sharing arrangements, the application of safeguards and, where applicable, international law principles, even if it is still open whether a final agreement on Ruzizi III can be reached. In contrast, the Xayaburi case illustrates that the picture may be different in the case of hydropower investments on transboundary rivers, if the investing state believes that it is in its self-interest to proceed with the respective hydropower investment outside the frame of regional organizations. In fact, as the Xayaburi case illustrates, new private investors from middle income countries may fundamentally change the power dynamics on international rivers despite the existence of an IRBO, and the latter's influence on investment projects by member states may be very limited: while Laos eventually adjusted the design of the Xayaburi dam to some extent, a moratorium on dam construction could not be imposed. This also points to the limits of regime theory in explaining power dynamics in international basins (e.g.,
Furlong, 2006; Zeitoun, 2007), and supports Weitz et al.'s contention that nexus governance may be limited by power dynamics. Beyond the factors highlighted by Weitz et al. (2017), the article also found that the assessment of impacts and nexus governance may be complicated by poor or disputed data.

The question is what recommendations can be drawn from the analysis. While regional organizations may play a role in WEF nexus governance, the Xayaburi case also points to their limits. At the same time, had the MRC not been in place, it is questionable whether adjustments would have been made to the design of the Xayaburi dam at all. Therefore, particularly in view of the increase in private sector investments in hydropower on international rivers, consideration should nevertheless be given to further setting up and strengthening regional organizations in order to support nexus governance (Dombrowsky and Scheumann, 2016). At the same time, the cases also show that environmental and social safeguards are important irrespective of the existence of regional organizations, even if the latter may support their application. Hence, also private sector initiatives, such as the Hydropower Sustainability Assessment Protocol of the International Hydropower Association, may be worth supporting to ensure nexus governance (IHA, 2010). This said, the cases also illustrate that the basin scale is rarely the scale of decision-making for energy investments, which points to the limits of influence of IRBOs. Hence, while nexus impact of hydropower investments should be studied at the basin scale, it would be inadequate to limit the analysis of nexus governance related to hydropower to the basin scale.

\section{AUTHOR CONTRIBUTIONS}

ID had the idea for this article. She drafted a first version of the introduction, the conceptual framework and the discussion section, and revised these based on substantial feedback and intellectual input by $\mathrm{OH}$. Field work for the African HPPs was carried out by ID, who also wrote the respective sections. Field work for the Xayaburi HPP was conducted by $\mathrm{OH}$, who wrote the respective sections.

\section{ACKNOWLEDGMENTS}

This paper was prepared in the context of the project 'Implementing the Water-Energy-Food Nexus: Incentive structures and policy instruments' funded by the German Federal Ministry for Economic Cooperation and Development (BMZ) (grant no. 2015.95.834). Field research in Africa was carried out within the Post-graduate Training Programme on Development Cooperation of the German Development Institute, and the contributions by Julia Bastian, Daniel Däschle, Simon Heisig, Johannes Peters and Christian Vosseler to the field research are greatly acknowledged. Field research for the Xayaburi dam was funded by a British Academy Small Research Grant 'Institutionalizing Environmental Norms for Large Dams: The Case of the Mekong River Commission' 
(grant number SG111140). The open access fee was covered by the 'BMZ project Implemeting the 2030 Agenda: Integrating Growth, Environment, Equality and Governance' (grant no. 2016.9595.6). The authors are indebted to EGL, MRC and NELSAP for hosting them and for their invaluable support

\section{REFERENCES}

ABAKIR (Autorité du Bassin du Lac Kivu et de la Rivière de Ruzizi) (2011). International Convention on the Integrated Management of Water Resources of the Lake Kivu and Ruzizi River Basin. no place: Autorité du Bassin du Lac Kivu et de la Rivière de Ruzizi/Lake Kivu and Ruzizi River Basin Authority.

Abbott, K. W., and Snidal, D. (1998). Why states act through formal international organizations. J. Confl. Resolut. 42, 3-32. doi: 10.1177/0022002798042001001

ARTELIA (2013). Rusumo Falls Hydroelectric Project-Dam \& Powerplant Component: Environmental and Social Impact Assessment (ESIA). Kigali: Nile Basin Initiative.

Basit, T. N. (2003). Manual or electronic? The role of coding in qualitative data analysis. Educ. Res. 45, 143-154. doi: 10.1080/0013188032000133548

Bastmeijer, K., and Koivurova, T. (2008). Theory and Practice of Transboundary Environmental Impact Assessment. Leiden; Boston, MA: Martinus Neijhoff Publishers.

Bauer, S. (2006). Does Bureaucracy really matter? The authority of intergovernmental treaty secretariats in global environmental politics. Glob. Environ. Politics 6, 23-49. doi: 10.1162/glep.2006.6.1.23

Bazeley, P. (2007). Qualitative Data Analysis With NVivo. London: Sage.

Bazilian, M., Rogner, H., Howells, M., Hermann, S., Arent, D., Gielen, D., et al. (2011). Considering the energy, water and food nexus: towards an integrated modelling approach. Energy Policy 39, 7896-7906. doi: 10.1016/j.enpol.2011.09.039

Bogner, A., Littig, B., and Menz, W. (2005). Das Experteninterview. Theorie, Methoden, Anwendung. Wiesbaden: VS Verlag.

Bryman, A. (2008). Social Research Methods. Oxford: Oxford University Press.

CEPGL (Communauté économique des Pays des Grands Lacs) (2012). Synthèse des données techniques de Ruzizi III. Bujumbura: Communauté économique des Pays des Grands Lacs.

Conca, K., Wu, F., and Mei, C. (2006). Global regime formation or complex institution building? The principled content of international river agreements. Int. Stud. Q. 50, 263-285. doi: 10.1111/j.1468-2478.2006.00402.x

Dombrowsky, I. (2007). Conflict, Cooperation and Institutions in International Water Management. An Economic Analysis. Cheltenham; Northampton, MA: Edward Elgar.

Dombrowsky, I. (2009). Revisiting the potential for benefit sharing in the management of trans-boundary rivers. Water Policy 11, 125-140. doi: 10.2166/wp.2009.020

Dombrowsky, I., Bastian, J., Daeschle, D., Heisig, S., Peters, J., and Vosseler, C. (2014). International and local benefit sharing in hydropower projects on shared rivers: the Ruzizi III and Rusumo Falls cases. Water Policy 16, 1087-1103. doi: 10.2166/wp.2014.104

Dombrowsky, I., and Scheumann, W. (2016). "Regional organisations promote Nexus governance for hydropower along international rivers," in Nexus Brief No. 6/2016 (Bonn: Deutsches Institut für Entwicklungspolitik).

Furlong, K. (2006). Hidden theories, troubled waters: International relations, the "territorial trap", and the Southern African Development Community's transboundary waters. Polit. Geogr. 25, 438-458. doi: 10.1016/j.polgeo.2005.12.008

Gallagher, L., Dalton, J., Bréthaut, C., Allan, T., Bellfield, H., Crilly, D., et al. (2016). The critical role of risk in setting directions for water, food and energy policy and research. Curr. Opin. Environ. Sustain. 23, 12-16. doi: 10.1016/j.cosust.2016.10.002

Gerlak, A., and Schmeier, S. (2016). "River basin organizations and the governance of transboundary watercourses," in Oxford Handbook on Water Politics and Policy, eds K. Conca and E. Weinthal (Oxford: Oxford University Press). doi: 10.1093/oxfordhb/9780199335084.013.20

Gerring, J. (2007). Case Study Research: Principles and Pratices. Cambridge: Cambridge University Press. in carrying out the interviews, and to all interview partners for their valuable time and inputs. Earlier versions of the paper benefited from discussions with Waltina Scheumann and helpful comments by Claudia Pahl-Wostl as well as two reviewers.

Gläser, J., and Laudel, G. (2009). Experteninterviews und Qualitative Inhaltsanalyse als Instrumente Rekonstruierender Untersuchungen. Wiesbaden: VS Verlag für Sozialwissenschaften.

Gupta, J. (2016). The watercourses convention, hydro-hegemony and transboundary water issues. Int. Spect. 51, 118-131. doi: 10.1080/03932729.2016.1198558

Hensel, P. R., McLaughin Mitchell, S., and Sowers, T. E. (2006). Conflict management of riparian disputes. Polit. Geogr. 25, 383-411. doi: $10.1016 /$ j.polgeo.2005.11.001

Hensengerth, O. (2015). Where is the power? Transnational networks, authority and the dispute over the Xayaburi Dam on the Lower Mekong Mainstream. Water Int. 40, 911-928. doi: 10.1080/02508060.2015.1088334

Hensengerth, O., Dombrowsky, I., and Scheumann, W. (2012). "Benefit-sharing in dam projects on shared rivers," in Discussion Paper 6/2012 (Bonn: Deutsches Institut für Entwicklungspolitik/German Development Institute).

Hoff, H. (2011). Understanding the Nexus. Background Paper for the Bonn 2011 Conference: The Water, Energy and Food Security Nexus. Stockholm: Stockholm Environment Institute.

ICEM (International Centre for Environmental Management) (2010). Strategic Environmental Assessment of Hydropower on the Mekong Mainstream: Summary of the Final Report. Hanoi: ICEM Australia.

ICPDR (International Commission for the Protection of the Danube River) (2013). Sustainable Hydropower Development in the Danube Basin. Vienna: International Commission for the Protection of the Danube River.

ICSU (International Council for Science) (2017). A Guide to SDG Interactions: From Science to Implementation. Paris: International Council for Science.

IHA (International Hydropower Association) (2010). Hydropower Sustainability Assessment Protocol. London: International Hydropower Association.

IHA (International Hydropower Association) (2017). Hydropower Status Report 2017. London: International Hydropower Association.

Jinnah, S. (2014). Post-Treaty Politics. Secretariat Influence in Global Environmental Governance. Cambridge, MA; London: The MIT Press.

Keohane, R. O. (1984). After Hegemony: Cooperation and Discord in the World Political Economy. Princeton, NJ: Princeton University Press.

Keohane, R. O. (1988). International institutions: two approaches. Int. Stud. Q. 32, 379-396. doi: 10.2307/2600589

Keskinen, M., Guillaume, J. H. A., Kattelus, M., Porkka, M., Räsänen, T. A., and Varis, O. (2016). The water-energy-food nexus and the transboundary context: insights from large Asian rivers. Water 8:193. doi: 10.3390/w8050193

Kirchherr, J. W., and Charles, K. J. (2018). Enhancing the sample diversity of snowball samples: recommendations from a research project on anti-dam movements in Southeast Asia. PLoS ONE 13:e0201710. doi: 10.1371/journal.pone.0201710

Klaphake, A. (2006). Cooperation on International Rivers From an Economic Perspective: The Concept of Benefit-Sharing. Bonn: Deutsches Institut für Entwicklungspolitik/German Development Institute.

Krasner, S. D. (1983). "Structural causes and regime consequences: regimes as intervening variables," in International Regimes, ed S. D. Krasner (Ithaca: Cornell University Press), 1-22.

Kurian, M. (2017). The water-energy-food nexus. Trade-offs, thresholds and transdisciplinary approaches to sustainable development. Environ. Sci. Policy 68, 97-106. doi: 10.1016/j.envsci.2016.11.006

Lebel, L., and Lebel, B. (2018). Nexus narratives and resource insecurities in the Mekong Region. Environ. Sci. Policy 90, 164-172. doi: 10.1016/j.envsci.2017.08.015

Leck, H., Conway, D., Bradshaw, M., and Rees, J. (2015). Tracing the waterenergy-food nexus: description, theory and practice. Geogr. Compass 9, 445-460. doi: 10.1111/gec3.12222.

LeMarquand, D. (1993). The International Joint Commission and changing Canada-United States boundary relations. Nat. Resour. J. 33, 59-91. 
LeMarquand, D. G. (1977). International Rivers. The Politics of Cooperation. Vancouver, BC: Westwater Research Center, University of British Columbia.

Linn, J. F., and Pidufala, O. (2008). "The experience with regional economic cooperation organizations: lessons for Central Asia," in Wolfensohn Center for Development Working Papers (Washington, DC: Brookings Global Economy and Development).

Marshall, C., and Rossman, G. B. (2006). Designing Qualitative Research. Thousand Oaks, CA: Sage Publications.

Matthews, N. (2012). Water grabbing in the Mekong Basin - an analysis of the winners and losers of Thailand's hydropower development in Lao PDR. Water Alternat. 5, 392-411.

Mayring, P. (2000). Qualitative Inhaltsanalyse. Forum Qualitat. Soc. Res. 1, 1-10.

McCaffrey, S. (2003). The Law of International Watercourses. Non-Navigational Uses. Oxford: Oxford University Press.

Middleton, C., Allouche, J., Gyawali, D., and Allen, S. (2015). The rise and implications of the water-energy-food nexus in Southeast Asia through an environmental justice lens. Water Alternat. 8, 627-654.

Middleton, C., and Dore, J. (2015). Transboundary water and electricity governance in mainland Southeast Asia: linkages, disjunctures and implications. Int. J. Water Govern. 1, 93-119. doi: 10.7564/14-IJWG54

MRC (Mekong River Commission) (2009). Preliminary Design Guidance for Proposed Mainstream Dams in the Lower Mekong Basin. Vientiane: Mekong River Commission.

MRC (Mekong River Commission) (2011). Knowledge Base on Benefit Sharing. Vientiane: Mekong River Commission.

MRC (Mekong River Commission) (2016a). Integrated Water Resources Management-based Basin Development Strategy 2016-2020 For the Lower Mekong Basin. Vientiane: Mekong River Commission.

MRC (Mekong River Commission) (2016b). Procedural Rules for Mekong Water Diplomacy. Procedures for Notification, Prior Consultation and Agreement (PNPCA). Vientiane: Mekong River Commission.

MRC (Mekong River Commission) (2017a). The Council Study: Key Messages from the Study on Sustainable Management and Development of the Mekong River Basin, including Impact of Mainstream Hydropower Projects. Vientiane: Mekong River Commission.

MRC (Mekong River Commission) (2017b). The Council Study: The Study on the Sustainable Management and Development of the Mekong River Basin, INCLUDING IMPACTS of Mainstream Hydropower Projects. Thematic Report on the Positive and Negative Impacts of Hydropower Development on the Social, Environmental, and Economic Conditions of the Lower Mekong River Basin. Vientiane: Mekong River Commission.

Müller, A., Janetschek, H., and Weigelt, J. (2015). Towards a governance heuristic for sustainable development. Curr. Opin. Environ. Sustain. 15, 49-56. doi: 10.1016/j.cosust.2015.08.007

NBI (Nile Basin Initiative) (2005). Strategic, Sectorial, Social and Environmental Assessment of Power Development Options in the Nile Equatorial Lakes RegionBurundi, Rwanda and Western Tanzania. Washington, DC: The World Bank.

Never, B., and Stepping, K. (forthcoming). Comparing urban wastewater systems in India and Brazil: options for energy efficiency and wastewater reuse. Water Policy (accepted). doi: 10.2166/wp.2018.216

ODI (Overseas Development Institute), ECDPM, (European Centre for Development Policy Management), and DIE, (Deutsches Institut für Entwicklungspolitik/German Development Institute) (2012). "Confronting scarcity: Managing water, energy and land for inclusive and sustainable growth," in European Report on Development 2011-2012 (Belgium).

Paavola, J. (2007). Institutions and environmental governance: a reconceptualization. Ecol. Econ. 63, 93-103. doi: 10.1016/j.ecolecon.2006.09.026

Pahl-Wostl, C. (in press). Governance of the water-energy-food security nexus: a multi-level coordination challenge. Environ. Sci. Policy, 1-12. doi: 10.1016/j.envsci.2017.07.017

Pittock, J., Dumaresq, D., and Bassi, A. M. (2016). Modeling the hydropowerfood nexus in large river basins: a mekong case study. Water 8, 425. doi: $10.3390 /$ w8100425

Pöyry (2011). Compliance Report, Government of Laos, Main Report: Xayaburi Hydroelectric Power Project Run-of-River Plan. Zürich: Pöyry.

Rangeley, R., Thiam, B., Andersen, R., and Lyle, C. (1994). "International River Basin Organizations in Sub-Saharan Africa," in World Bank Technical Paper (Washington, DC: World Bank).
Rasul, G., and Sharma, B. (2016). The nexus approach to water-energy-food security: an option for adaptation to climate change. Clim. Policy 16, 682-702. doi: 10.1080/14693062.2015.1029865

Sadoff, C. W., and Grey, D. (2002). Beyond the river: the benefits of cooperation on international rivers. Water Policy 4, 389-403. doi: 10.1016/S1366-7017(02)00035-1

Saruchera, D., and Lautze, J. (2016). Transboundary river basin organizations in Africa: assessing the secretariat. Water Policy 18, 1053-1069. doi: $10.2166 /$ wp. 2016.228

Scheumann, W., Dombrowsky, I., and Hensengerth, O. (2014). "Dams on shared rivers: the concept of benefit sharing," in The Global Water System in the Anthropocene: Challenges for Science and Governance, eds J. Bogardi, A. Bhaduri, J. Leentvaar, and S. Marx (Heidelberg: Springer), 105-124.

Scheumann, W., and Tigrek, S. (2015). Regional energy trading-a new avenue for resolving a regional water dispute? Int. J. Water Govern. 1, 1-22. doi: $10.7564 / 14$-ijwg 46

Schiff, M., and Winters, A. (2002). "Regional cooperation and the role of international organizations and regional integration," in World Bank Policy Research Working Paper (Washington, DC: The World Bank).

Schmeier, S. (2013). Governing International Watercourses: River Basin Organizations and the Sustainable Governance of Internationally Shared Rivers and Lakes. London: Routledge.

Schmeier, S., Gerlak, A., and Blumstein, S. (2016). Clearing the muddy waters of shared watercourses governance: conceptualizing international River Basin Organizations. Int. Environ. Agreem. Polit. Law Econ. 16, 597-619. doi: 10.1007/s10784-015-9287-4

Smajgl, A., Ward, J. R., Foran, T., Dore, J., and Larson, S. (2015). Visions, beliefs, and transformation: exploring cross-sector and transboundary dynamics in the wider Mekong region. Ecol. Soc. 20, 15. doi: 10.5751/es-07421-200215

SNC Lavalin International (2008). Regional Rusumo Falls Hydro-Electric and Multipurpose Project: Final Baseline Report. Kigali.

SNC Lavalin International (2012). Rusumo Falls Hydroelectric Power Development Project-Feasibility Study-Intermediate Development Scheme-Environmental and Social Impact Assessment Report. Kigali: Nile Ecquatorial Lakes Subsidiary Action Program.

SOFRECO, Inc., R., and Mercados (2012). Etude d'Impact Environnemental et Social (EIES) et Plan d'Action et de Réinstallation (PAR) de l'Aménagement Hydroélectrique de Ruzizi III. Rapport Final du Consultant sur le Plan d’action et de Reinstallation. Volume 1: Rapport Principal (no place).

Stein, A. A. (1982). Coordination and collaboration: regimes in an Anarchic World. Int. Organ. 36, 299-324. doi: 10.1017/S0020818300018968

Stein, C., Barron, J., and Moss, T. (2014). "Governance of the nexus: from buzz words to a strategic action perspective," in Nexus Network Think Piece Series (Brighton, UK: The Nexus Network).

Strasser, L. D., Lipponen, A., Howells, M., Stec, S., and Bréthaut, C. (2016). A methodology to assess the water energy food ecosystems nexus in transboundary river basins. Water 8, 1-28. doi: 10.3390/ w8020059

Suhardiman, D., Giordano, M., and Molle, F. (2015). Between interests and worldviews: the narrow path of the Mekong River Commission. Environ. Plan. C-Govern. Policy 33, 199-217. doi: 10.1068/c11191

Tawfik, R., and Dombrowsky, I. (2018). "GERD and hydro-politics in the Eastern Nile: from water to benefit-sharing?" in The Grand Ethiopian Renaissance Dam and the Nile Basin: Implications for Transboundary Water Cooperation, eds. Z. Yihdego, A. Rieu-Clarke, and A. Cascao (London: Routledge), 113-137.

UNECE (United Nations Economic Commission for Europe) (1991). Convention on Environmental Impact Assessment in a Transboundary Context. Espoo, Finland: United Nations.

UNECE (United Nations Economic Commission for Europe) (2015). Reconciling Resource Uses in Transboundary Basins: Assessment of the Water-Food-EnergyEcosystems Nexus. New York, Geneva: United Nations.

UNEP (2014). "Governing the water-energy-food nexus: opportunities for basin organisations," in First International Environment Forum for Basin Organizations. Towards Sustainable Freshwater Governance. 26-28 November 2014, Nairobi, Kenya. Technical background document for theme 2: "Water-Energy-Food Nexus" (Nairobi: United Nations Environment Programme). 
Villamayor-Tomas, S., Grundmann, P., Epstein, G., Evans, T., and Kimmich, C. (2015). The water-energy-food security nexus through the lenses of the value chain and the institutional analysis and development frameworks. Water Alternat. 8, 735-755.

WCD (World Commission on Dams) (2000). Dams and Development: A New Framework for Decision-Making. London: Earthscan.

WEF-WI (World Economic Forum-Water Initative) (2011). Water Security. The Water-Food-Energy-Climate Nexus. Washington, DC: Island Press.

Weitz, N., Strambo, C., Kemp-Benedict, E., and Nilsson, M. (2017). Closing the governance gaps in the water-energy-food nexus: insights from integrative environmental governance. Glob. Environ. Change 45, 165-173. doi: 10.1016/j.gloenvcha.2017. 06.006

Yin, R. K. (1994). Case Study Research: Design and Methods. Thousand Oaks, CA: Sage Publications.
Zeitoun, M. (2007). The conflict vs. cooperation paradox: fighting over or sharing of Palestinian-Israeli groundwater? Water Int. 32, 105-120. doi: $10.1080 / 02508060708691968$

Conflict of Interest Statement: The authors declare that the research was conducted in the absence of any commercial or financial relationships that could be construed as a potential conflict of interest.

Copyright (c) 2018 Dombrowsky and Hensengerth. This is an open-access article distributed under the terms of the Creative Commons Attribution License (CC BY). The use, distribution or reproduction in other forums is permitted, provided the original author(s) and the copyright owner(s) are credited and that the original publication in this journal is cited, in accordance with accepted academic practice. No use, distribution or reproduction is permitted which does not comply with these terms. 